\title{
The Implementation of SST as the System of Room Reservation for Students' Organization at Atma Jaya BSD Campus
}

\author{
Ferdian Aditya Pratama ${ }^{1}$, Stefani Prima Dias Kristiana ${ }^{2}$, Christian Moritz Lukito ${ }^{3}$ \\ Faculty of Engineering \\ Atma Jaya Catholic University of Indonesia \\ ${ }^{1}$ ferdian.aditya@atmajaya.ac.id, ${ }^{2}$ stefani.primadyas@atmajaya.ac.id, \\ ${ }^{3}$ christian.2016043046@student.atmajaya.ac.id
}

\begin{abstract}
The implementation of SST in any organization activity can create a positive outcome and bring less negative response if the system failed. The bureau of students, alumni, and student career counselling at Atma Jaya has difficulties managing a room booking process for the student's organization. The current method of room booking is done manually, and it has taken a lot of costs, especially from time, human resources, and the process itself. This research focuses on developing the SST system that can help the bureau manage the room booking process. The system itself will be developed on a web-based platform using Laravel as the framework. The room booking system will be developed using an SDLC model with five general processes: planning, analysing, design, implementation, and testing. This research will also measure user satisfaction while using the system using Kaplan and Norton Model. The result of this study is a web-based system for a room booking process for students' organizations in Atma Jaya BSD Campus. Based on the evaluation of user satisfaction, this system has an average score of 4.56, which indicates the user is very satisfied using this system for the room reservation.
\end{abstract}

Keywords - Kaplan and Norton model, Room booking system, SST, web-based system.

\section{INTRODUCTION}

Self-service technology is starting to apply in many industries, such as governments, education, healthcare, financial services, and retail [1]. There are many types of implementations of SST, such as internet- based services, check-in systems, eCommerce, etc. [2]. It is also starting to replace the service employees because of their competitive advantages [3]. Some industries mention that Self-service technology (SST) has become a critical element, especially in controlling costs and improving customer experience [4]. The use of self-service technology can become helpful, especially if the user is in the group of the Y Generation because of the intensive use of technology itself [5]. By using the SST, users can obtain fast service processes and reduce wait times [6]. In addition, based on previous research, users are willing to use SST because it is easy to use [7]. Because of the significant gap between traditional services and SST, the implementation of SST in every process business is necessary [8]. Implementing SST in a process business can bring less negative response if the system fails to manage some processes [9] and can create a positive service outcome such as user satisfaction [10].

At Atma Jaya Catholic University of Indonesia, a bureau of students, alumni, and student career counselling needs to implement the SST. The bureau is responsible for managing all the student's activities, starting from a room book for students' activities to propose a new activity. Based on the interview with one of the staff from the bureau, the most unreadiness activity from the bureau is about the room reservation to support every student's activities, especially in Atma Jaya's new campus (BSD Campus). The reservation was made manually, which causes a lot of conflicts on the reservation schedule. The manual reservation process takes a lot of 
costs, starting from time, human resources, and the process itself.

Based on that problem, the implementation of SST is essential. The previous study states that a clean-room reservation process in an organization can significantly affect collaboration in an organization's activity [11]. The implementation of SST can also provide an organization in reducing operational costs [12]. The development process of the SST will use SDLC as a methodology. SDLC is considered the critical concept used in software engineering to describe the overall process in software development [13]. The purposes of this research are (1) to identify and design the less-cost reservation process using a UML diagram, (2) to develop the SST of room reservation using a Laravel framework as a web-based platform, and (3) to identify the satisfaction of the users using the SST system. Currently, the system is still in use only at Atma Jaya's new campus (BSD Campus). And the students' organizations involved in using the system are students' organizations from the Faculty of Engineering and the Faculty of Biotechnology. The result of this research is a web-based platform of SST for room reservation in the bureau of students, alumni, and student's career counselling of Atma Jaya Catholic University of Indonesia.

The previous study discusses the development of SST for helpdesk using Framework ITIL V3 [14]. This research use Grails as the web-based framework. Based on the acceptance testing, the system has a great score in user acceptance testing $(88.89 \%$ for the UI and $83.71 \%$ for the functionalities). The user satisfaction is not tested yet in this research. In this current research, the use of Laravel framework will be carried out in the development process. The measurement of user satisfaction in the current study will use Kaplan and Norton Model.

Another previous study discusses the development process of inventory information systems as the implementation of SST for midwifery academics [15]. This research uses native PHP as a programming language and SQL Server as the database. The result finds from this research is the implementation of SST can become significantly handy, especially in managing an inventory. In this current research, the development of SST for room reservation will use Laravel as the framework. The current research will also measure user satisfaction in using the system.

\section{METHOD}

The methodology uses in this research is shown in Figure 1.

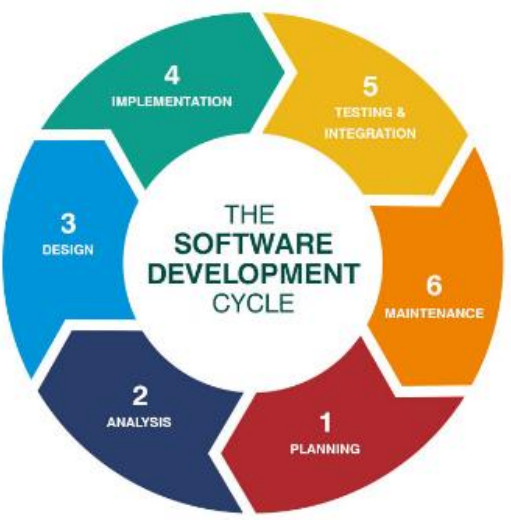

Figure 1. SDLC Methodology

In general, there are five steps done in this research: (1) planning, (2) analysis, (3) design, (4) implementation, and (5) testing. The first step is planning. In this phase, identifying the old business process held by the bureau is made, starting from identifying any documents included, entities involved in the process, and reservation flow. The study literature was also carried out in this phase. Because of the manual process in room reservation, there is no relation between all the entities involved in the process.

In the analysis phase, the flowchart for the room reservation system is developed. The processes have become more straightforward because there are some approval steps from some bureau that are skipped. The flowchart of the room reservation is shown in Figure 2. 


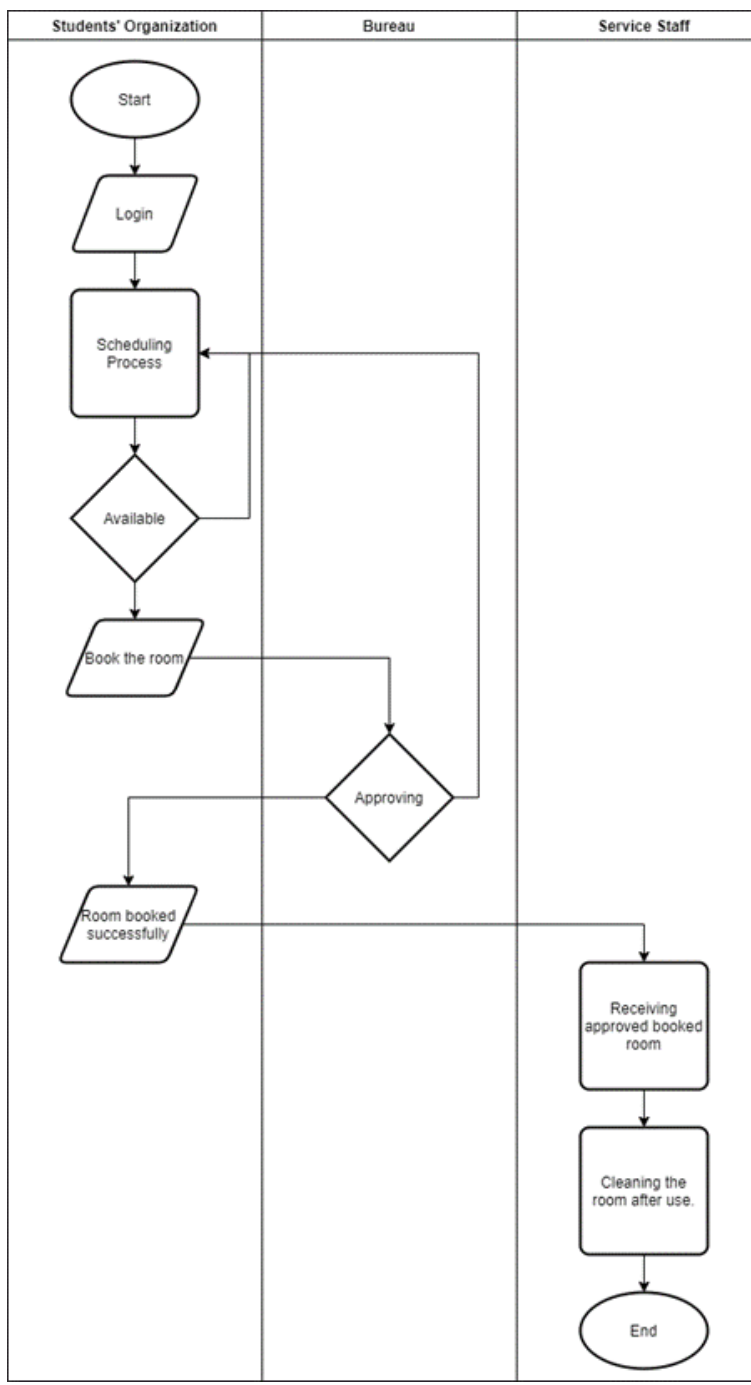

Figure 2. Flowchart of the Room Reservation System

Based on figure 2, every student's organization will have an account to access the system. They are required to login into the system to proceed with the reservation process. The significant difference between the manual process and the system process is explained in Table 1.

\section{Table 1. Comparative Process Between and} Manual Reservation Process

\begin{tabular}{ll}
\hline \multicolumn{1}{c}{ Manual Process } & \multicolumn{1}{c}{ System Process } \\
\hline $\begin{array}{l}\text { Must fill up a form to } \\
\text { reserve a room }\end{array}$ & $\begin{array}{l}\text { Need an account to } \\
\text { login into the system }\end{array}$ \\
\hline $\begin{array}{l}\text { The limited operational } \\
\text { time of the bureau (only } \\
\text { three days in a week) }\end{array}$ & $\begin{array}{l}\text { The system can be } \\
\text { anytime. }\end{array}$ \\
\hline $\begin{array}{l}\text { Students need to come } \\
\text { to the bureau office to }\end{array}$ & $\begin{array}{l}\text { The availability of the } \\
\text { room can be checked in } \\
\text { the system. } \\
\text { the rooms the availability of }\end{array}$ \\
\end{tabular}

Need approval from the Only need approval bureau of students, from the head of alumni, and student's organizations at the career counselling and faculty level. the head of student's organization at the faculty level

$\begin{array}{ll}\text { The approval form must } & \text { The approval form } \\ \text { be printed and handed } & \begin{array}{l}\text { doesn't need to be } \\ \text { over to the service staff. }\end{array} \\ \text { printed. }\end{array}$

In the design phase, the UML diagrams such as use case and class diagram are designed. The use case for the system is shown in Figure 3.

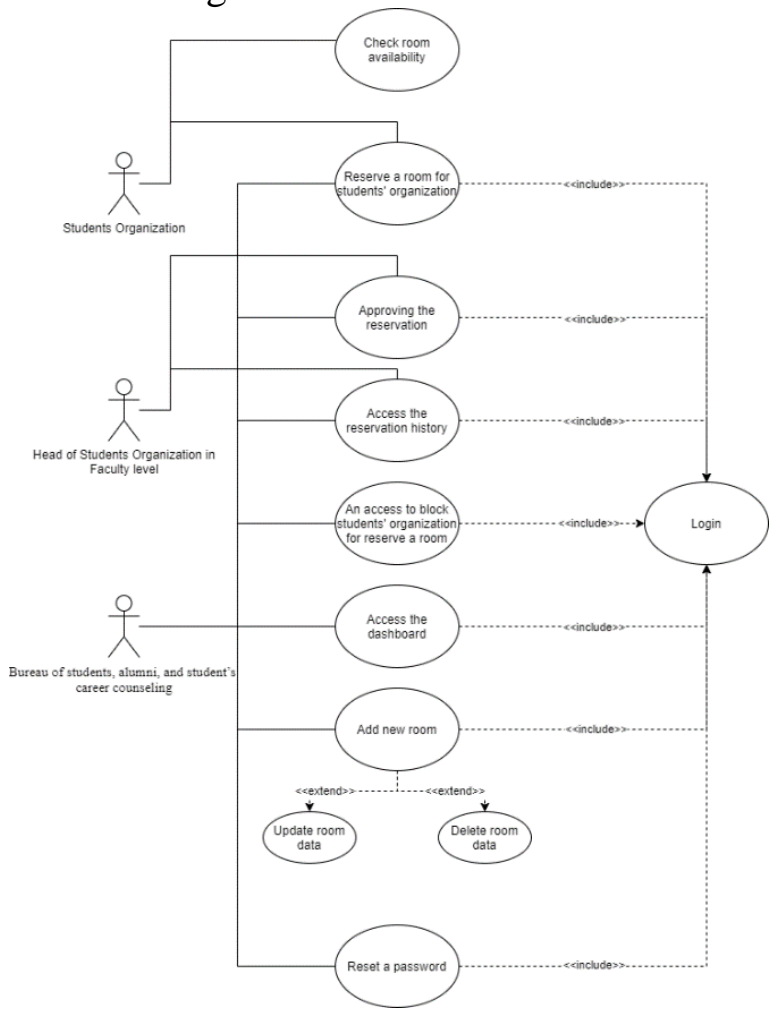

Figure 1. Use Case Diagram

There are three main actors in the system: (1) students' organization, (2) the head of student organization in faculty level, and (3) the bureau of students, alumni, and student's career counselling. The bureau has an admin role in the system, and it has access to all the functions in the system. The head of student's organization only has access to approving the reservation request from the student organization and seeing the reservation's history. Meanwhile, the student's organization only has access to submit a request for room reservation and check the availability of the rooms. The class 
diagram designed in this research is shown in Figure 4.

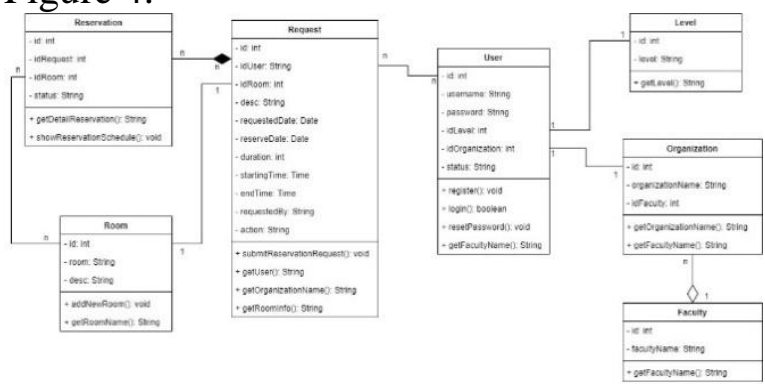

Figure 2. Class Diagram

There are seven classes used in this system: (1) request, which has a relation with (2) reservation, (3) room, and (4) user class. The relation between reservation and request class is a composition, meaning the reservation class cannot exist if the request class is not executed. The user class also has a relation with (5) level and (6) organization class, and the organization class has an aggregation relation with the (7) faculty class, meaning the organization class is part of the faculty class. The user of this system was also involved in the design process.

In the implementation phase, the coding step based on the design phase will be carried out. The system is developed using Laravel as the framework and PHP as its primary language and use MySQL as its database. In the testing phases, the system will be tested based on its functionality and user satisfaction. The functionality testing will be carried out by using Black-box testing and test-café studio as the tool. The user satisfaction was tested after one month trial using the system in the real environment. The questionnaire was distributed to 20 respondents to measure user satisfaction and will use the Kaplan and Norton Model as its reference. The satisfaction rating based on the Kaplan and Norton model is shown in Table 2.

Table 2.Satisfaction Rating

\begin{tabular}{cc}
\hline Range & Description \\
\hline $1-1.79$ & Very dissatisfied \\
\hline $1.8-2.59$ & Dissatisfied \\
\hline $2.6-3.39$ & Doubtful \\
\hline $3.4-3.91$ & Satisfied \\
\hline $4.2-5$ & Very Satisfied \\
\hline
\end{tabular}

\section{RESULT AND DISCUSSION}

The room reservation system was developed on the website platform and stored at Atma Jaya server. The website can be accessed through the internet. The home page of the system is shown in Figure 5.

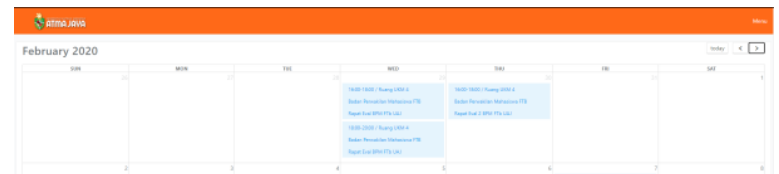

Figure 5. Design of Library Infrastructure

From the home page, all the users in the system can have access to the schedule of rooms reserved. The calendar layout on the home page aims so that users can easily see the reserved room. The login page is shown in Figure 6.

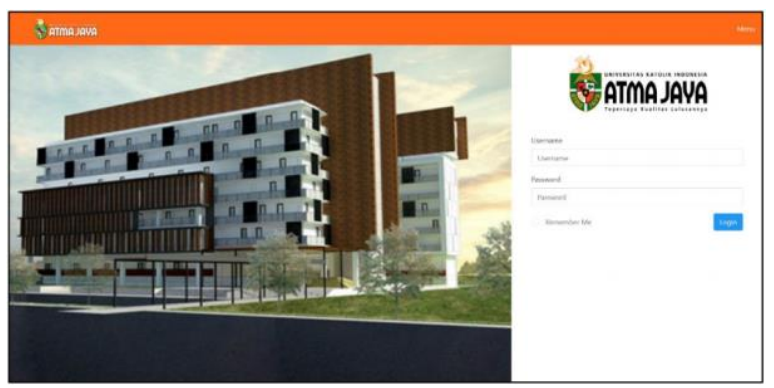

Figure 6. Login Page of System

All the student organizations' IDs will be shared to the organizations' email. All the student organizations must $\log$ in to the system to reserve a room for their activities. The request booking in the system is shown in Figure 7.

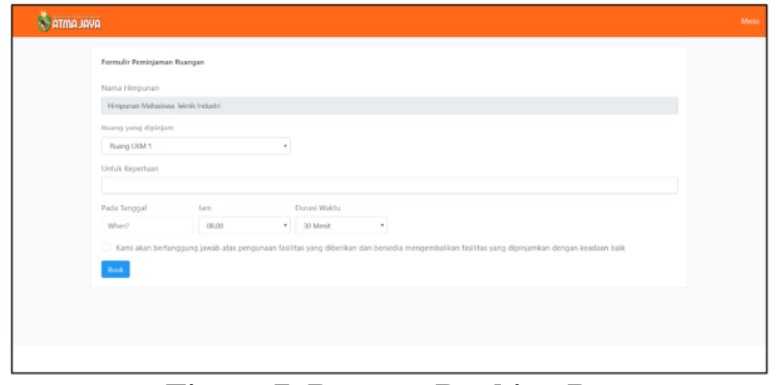

Figure 7. Request Booking Page 
The field organization name is a read-only field in the request form and will be automatically filled by the system based on the organization id stored in the database. As for the room, description, date, time, and duration fields must be filled by the user. All the requested forms must have the approval status from the head of the students' organization at the Faculty level. The approval page for the head of the students' organization is shown in Figure 8.

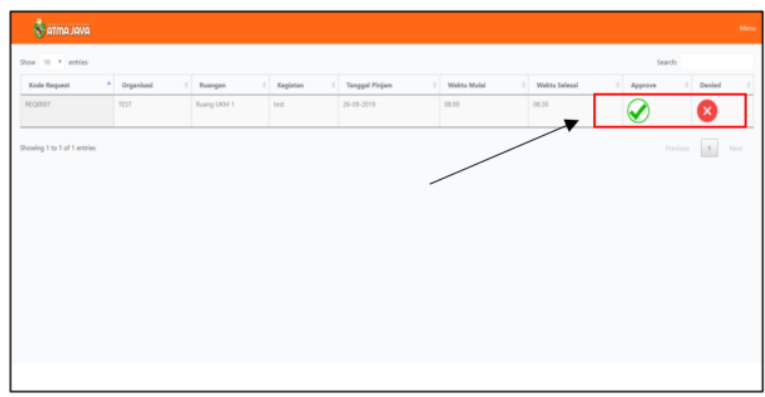

Figure 8. The Approval Page

The approval page in Figure 8 is only visible for the head of the students' organization. The actor only needs to select approve (check) button or the decline (cross) button on this page. The requested booking accepted by the head of the students' organization will automatically appear on the home page.

The functional testing of this system is done using a black-box testing method, and it is done automatically using the Test-Café Studio tool. Figure 9 shows the testing process using the Test-Café Studio.

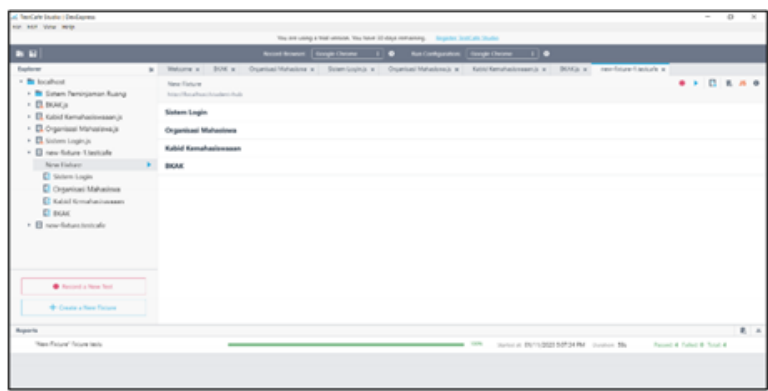

Figure 9. Testing Phase Using Test-Cafe Studio

The testing process tests all the main core functionality on the system. The list of the main core functionality is shown in Table 3 .
Table 3. Main Core Functionality Tested using Black-Box Testing

\begin{tabular}{|c|c|}
\hline Function & Testing Condition \\
\hline \multirow[t]{2}{*}{ Login } & $\begin{array}{l}\text { Username and password } \\
\text { inputted correctly }\end{array}$ \\
\hline & $\begin{array}{l}\text { Either Username or password } \\
\text { inputted incorrectly }\end{array}$ \\
\hline Schedule & $\begin{array}{l}\text { All the approved requests are } \\
\text { shown on the home page } \\
\text { calendar. }\end{array}$ \\
\hline \multirow[t]{2}{*}{$\begin{array}{l}\text { Request } \\
\text { booking }\end{array}$} & $\begin{array}{l}\text { All the input fields are filled } \\
\text { correctly }\end{array}$ \\
\hline & $\begin{array}{l}\text { Some input fields are filled } \\
\text { incorrectly }\end{array}$ \\
\hline Schedule check & $\begin{array}{l}\text { The system checks the } \\
\text { requested schedule } \\
\text { automatically before submitting } \\
\text { the request. }\end{array}$ \\
\hline \multirow[t]{2}{*}{$\begin{array}{l}\text { Approving } \\
\text { request }\end{array}$} & $\begin{array}{l}\text { The requested schedule appears } \\
\text { in the home page calendar after } \\
\text { the approve button is clicked. }\end{array}$ \\
\hline & $\begin{array}{l}\text { The requested schedule does not } \\
\text { appear in the home page } \\
\text { calendar after the decline button } \\
\text { is clicked }\end{array}$ \\
\hline \multirow[t]{4}{*}{$\begin{array}{l}\text { CRUD process } \\
\text { of room's data }\end{array}$} & $\begin{array}{l}\text { Room's data is successfully } \\
\text { inserted into the database when } \\
\text { all the required fields are filled } \\
\text { correctly and failed when not. }\end{array}$ \\
\hline & $\begin{array}{l}\text { Room data can be successfully } \\
\text { retrieved from the database. }\end{array}$ \\
\hline & $\begin{array}{l}\text { The room's data is updated } \\
\text { successfully based on the data } \\
\text { ID. }\end{array}$ \\
\hline & $\begin{array}{l}\text { The room's data can be } \\
\text { successfully deleted when the } \\
\text { OK button is hit on the } \\
\text { confirmation message. }\end{array}$ \\
\hline
\end{tabular}

The user satisfaction testing involved ten respondents with a representative of one person for each student organization in the Faculty of Engineering and Faculty of Biotechnology, including the bureau and the head of the students' organization on the faculty level. User satisfaction is measured for each of the main functionality on the system. The measurement was carried out by distributing a questionnaire with the scale of answers 1 (very dissatisfied) -5 (very satisfied). The result of the user satisfaction measurement is shown in Table 4. 
Table 4. User Satisfaction Score

\begin{tabular}{lcccccc}
\hline \multirow{1}{*}{ Function } & \multicolumn{7}{c}{ Score } & Total \\
\cline { 2 - 6 } & 5 & 4 & 3 & 2 & 1 & \\
\hline $\begin{array}{l}\text { Calendar (Home } \\
\text { Page) }\end{array}$ & 11 & 8 & 1 & 0 & 0 & $\mathbf{4 . 6 5}$ \\
\hline $\begin{array}{l}\text { Requesting room } \\
\text { reservation } \\
\text { (Students only) }\end{array}$ & 7 & 6 & 1 & 0 & 0 & $\mathbf{4 . 4 2}$ \\
\hline $\begin{array}{l}\text { Approval (head } \\
\text { of student's } \\
\text { organization only }\end{array}$ & 2 & 2 & 0 & 0 & 0 & $\mathbf{4 . 5}$ \\
\hline $\begin{array}{l}\text { Admin features } \\
\text { (bureau only) }\end{array}$ & 6 & 2 & 0 & 0 & 0 & $\mathbf{4 . 7 5}$ \\
\hline Overall system & 22 & 16 & 2 & 0 & 0 & $\mathbf{4 . 5}$ \\
\hline
\end{tabular}

Based on Table 4, user satisfaction scores for every main core function in the system have a score above 4.2. Based on the satisfaction rating in Table 2 , the system got a very satisfactory score.

\section{CONCLUSION}

Compared with the manual process of room reservation in Atma Jaya's BSD Campus for students' organization, the implementation of SST has the convenience of booking a room. The reservation system also can be accessed at anytime and anywhere. The system's functionalities also have a valid result based on the black-box testing, meaning all the obtained results from the system functionalities match the expected result. The system also gained an average score of 4.56 from the satisfaction score, which indicates the user is very satisfied using this system for the room reservation in Atma Jaya BSD campus.

\section{REFERENCES}

[1] H. Taherdoost, "Development of an adoption model to assess user acceptance of e-service technology: EService Technology Acceptance Model," Behaviour \& Information Technology, vol. 37, no. 2, pp. 173197, 2018.

[2] M. U. Hassan, M. S. Iqbal and U. Habibah, "Self-Service Technology Service Quality: Building Loyalty and Intention Through Technology Trust in
Pakistani Service Sector," SAGE Open, vol. 10, 2020.

[3] W. Feng, R. Tu, T. Lu and Z. Zhou, "Understanding forced adoption of self-service technology: the impacts of users' psychological reactance," Behaviour \& Information Technology, vol. 38, no. 8, pp. 820-832, 2019.

[4] E. Considine and K. Cormican, "Selfservice technology adoption: An analysis of customer to technology interactions," in CENTERIS, 2016.

[5] N. Gures, H. Inan and S. Arslan, "Assessing the self-service technology usage of Y-Generation in airline services," Journal of Air Transport Management, vol. 71, pp. 215-219, 2018.

[6] C. Yoon and B. Choi, "Role of Situational Dependence in the Use of Self-Service Technology," Sustainability, vol. 12, pp. 4653-4664, 2020.

[7] H. Shin and B. Dai, "The efficacy of customer's voluntary use of selfservice technology (SST): a dual-study approach," Journal of Strategic Marketing, pp. 1-23, 2020.

[8] J. Collier, R. S. Moore, A. Horky and M. L. Moore, "Why the little things matter: Exploring situational influences on customers' self-service technology decisions," Journal of Business Research, vol. 68, no. 3, pp. 703-710, 2015.

[9] T. Um, T. Kim and N. Chung, "How does an Intelligence Chatbot Affect Customers Compared with Self-Service Technology for Sustainable Services?," Sustainability, vol. 12, pp. 5119-5140, 2020.

[10] M. S. Iqbal, M. U. hassan and U. Habibah, "Impact of self-service technology (SST) service quality on customer loyalty and behavioral intention: The mediating role of customer satisfaction," Cogent Business \& Management, vol. 5, 2018.

[11] S. Atkinson and K. Lee, "Design and Implementation of a Study Room 
Reservation System: Lessons from a Pilot Program Using Google Calendar," College \& Research Libraries, vol. 79, no. 7, pp. 916-930, 2018.

[12] E. Fernando, S. Surjandy, M. Meyliana, H. A. Wijadja, D. Hidayat, A. W. Kusumaningtyas and R. Heryatno, "Factors Influencing the Intention to Use Technology Services to Implement Self-Service Technology Case Study: Situation Pandemic Covid19," Advances in Science, Technology and Engineering Systems Journal, vol. 5, no. 5, pp. 342-347, 2020.

[13] M. Sharma, "A study of SDLC to develop well engineered software," International Journal of Advanced Research in Computer Science, vol. 8, pp. 520-523, 2017.

[14] E. M. Sipayung, C. Fiarni and E. Aditya, "Perancangan Sistem Informasi Helpdesk Menggunakan Framework ITIL V3" JNTETI, vol. 6, no. 2, pp. 141-151, 2017.

[15] D. Susandi and Sukisno, "Sistem Informasi Inventaris Berbasis Webdi Akademi Kebidanan Bina Husada Serang," Jurnal Sistem Informasi, vol. 5, no. 2, pp. 46-50, 2018. 